\title{
Are Accelerated Degrees the Future for Higher Education?
}

lain L Kitchener

University of Greenwich

\begin{abstract}
As the government pushes though the Higher Education and Research Bill, universities have an unprecedented opportunity to add well-funded accelerated degrees to their portfolios (Department for Education, 2016).

To ensure high-quality outcomes and positive student experiences, we need to establish a well-researched pedagogy for accelerating learning alongside an accelerated delivery.
\end{abstract}

\section{Are Accelerated Degrees the Future for Higher Education?}

This is clearly a provocative question, though recent announcements about raising the yearly fees universities can charge students on accelerated degree programmes should give us pause for thought. The author is currently, at The University of Greenwich, the programme leader of, and teacher on, an accelerated degree course in primary education without qualified teacher status (QTS). This compresses a full 360-credit BA (Hons) into two academic years. If we chose to engage further with this approach, what would be the consequences for the higher education (HE) sector and how would such a decision fit within the strategic aims of institutions such as Greenwich? This article will explore the drivers for accelerated degrees, identify some of the issues surrounding the initiative and consider important next steps towards ensuring that such a project is truly successful. This article will conclude by arguing that effective accelerated degrees require more than the simple reduction of a three-year programme to a two-year time frame.

The increase in accelerated degrees is being driven in part by government policy. The Conservative Party Manifesto outlined, as part of the reform of university funding, that the Conservatives would "encourage universities to offer more two-year courses" (Conservative Party, 2015, p. 35). More recently, the government published findings which concluded that there was indeed a demand by students and employers for accelerated programmes and that post-92 universities would be the most likely to offer such programmes. However, some, like Scott (2017), argue that Minister for Universities, Science and Innovation Jo Johnson's backing of two-year degrees is likely to lead to only a few hundred such accelerated students, an argument put in doubt by the fact that the report also identified as key benefits reduced costs for students and quicker access to the graduate job market.

For many students, finance is arguably an overriding and entirely pragmatic concern when they make their choice of study. Our own programme has a mix of students, including those who opted for a cost-effective route to graduation. The current arrangements ensure that they complete the full 360 credits of an honours degree at a cost equivalent to that for 240 credits. However, this has a significant impact on staff workload, since the finance currently limited by the Office for Fair Access (OFFA) to $£ 9,000$ p.a. - brought into the Faculty does not equal the staff time required to teach those students. Lifting the cap on the amount universities can charge for tuition fees would certainly help ameliorate the problems 
of teaching 180 credits in a year (Stockwell, 2012), but this might be where things become more complicated. More controversially, Stockwell goes on to suggest that students who are studying as 'full time' in fact have plenty of space for additional courses of study during the academic year because they are so often lightly timetabled.

The findings (2016) of the Department for Education (DfE) identify one benefit of accelerated programmes as a means of speeding student access to the labour market. Another selling point for increasingly competitive universities is the option for students to enter the market via a Masters-level qualification within just three years. For Fielden and Middlehurst (2017), the move to allow accelerated degrees is tied to the fact that alternative providers already offer accelerated learning and progression to Masters. They identify that the Higher Education and Research Bill is broadly driven by the desire to increase competition and innovation between existing providers, but that it is predicated on an ideological belief that increased competition will serve to raise standards across the entire HE sector. The concern might be that such an approach to higher education will serve only to undermine quality and to water down the integrity of the sector.

The DfE has identified several barriers to the implementation of accelerated programmes. These include: a lack of student awareness that such routes exist; the incompatibility of certain externally-regulated courses, such as nursing or teaching; concerns about how such programmes would be valued internationally; the impact on staff research activity if teaching extends beyond the traditional term times; a reduction in summer vacation time during which students can earn. (Department for Education, 2016) However, whether these need be issues of concern really depends on the model of acceleration which is adopted.

In the United States, accelerated degrees have been around for many years. The Washington State Council of Presidents (2016) defines these as "an innovative approach to improve college affordability, address workforce needs and increase degree completion." The American Association of State Colleges and Universities (AASCU, 2012) defined four models for such programmes, one of which, the compression model, fits with that being promoted through the Higher Education and Research Bill and this model does address concerns raised in the previous paragraph. Completing the study during normal term times would avoid a reduction in student and staff time for other activity during the summer.

The final issue is arguably by far and away the most serious for us, as teachers and academics, to address. Although authors such as Davies, Slack and Howard (2012) found that there were no significant differences in outcomes between accelerated and traditional three-year students, this remains an area of limited research. It could be proposed that a successful accelerated degree programme cannot simply be three years of study delivered over two. Such a choice would be perilous at best, because the learning is forced to progress through levels 4-6 during that compressed time frame. This presents new challenges and it is my belief that a pedagogy for accelerated degree level learning will be required if students are to achieve the greatest possible amount of learning. Blended learning has much to offer in this regard, as may transformative learning theory (Mezirow, 1997), in forcing the development of critical analysis and more meaningful changes in frames of reference for our students as part of accelerating that process of learning. The learning gain of students from any discipline on an accelerated programme is likely to depend upon a range of factors. It is possible that we might construct a framework for 
accelerated progress which can be bolted to any programme and discipline, but the effective action research necessary to produce this result has yet to be undertaken.

I would argue that there is a core need for an accelerated curriculum which guarantees both the development of academic skills in tandem with subject knowledge and the fundamental transformation of the learner. Though we may glean much from the experience of accelerated programmes in the US, we must seek to refine the process within our own context if this is to be really successful for our own students.

The University of Greenwich already runs an accelerated degree in primary education and degrees in Language and Literacy and Mathematics Education which can serve as test beds for the pedagogical development outlined above. The University's Primary Department blazed the way over the last three years, but decisions are now required about how to place these programmes within a mixed-economy portfolio, alongside degree-level apprenticeships and extended degrees. At a time when funding is strained, decisions must be made about fees, value for money and support for accelerated students. Yet, of greater importance to the success of this new enterprise is the need for a pedagogy to be generated through research and engagement with the teaching community and with the support of academic development units. It is not only the time frame which must accelerated, but also the learning gain of students. In this way, the established university sector can confidently diversify its portfolio, address government policy and meet the needs of a wider range of students in the future. Change could indeed start here.

\section{Reference list}

Conservative Party. (2015) The Conservative Party Manifesto 2015. England: The Conservative Party. Available at: https://s3euwest1.amazonaws.com/manifesto2015/ConservativeManifesto2015.pdf (Accessed: 1 March 2017).

Department for Education (2016) Findings from the Call for Evidence on Accelerated Courses and Switching University or Degree. Available at:

https://www.gov.uk/government/uploads/system/uploads/attachment_data/file/579438/Findin gs_from_the_Call_for_Evidence_on_Accelerated_Courses_and_Switching_University_or_D egree.pdf (Accessed: 1 March 2017).

Department for Education (2016) Higher Education and Research Bill. Available at: https://www.publications.parliament.uk/pa/bills/lbill/2016-2017/0097/17097.pdf (Accessed: 10 March 2017).

Elmes, J. (2017) 'UK Government Warned Over Two-Year Degree Proposal.' Times Higher Education. Available at: https://www.timeshighereducation.com/news/uk-governmentwarned-over-two-year-degree-proposal (Accessed: 1 March 2017).

Fielden, J. and Middlehurst, R. (2017) Alternative Providers of Higher Education: Issues for Policy Makers. Higher Education Policy Institute. Available at: http://www.hepi.ac.uk/wp- 
content/uploads/2017/01/Hepi_The-alternative-providers-of-higher-education-Report-9004_01_17-Screen2.pdf (Accessed: 1 March 2017).

HEFCE (2011) Costing study of two-year accelerated honours degrees. Available at: http://www.hefce.ac.uk/media/hefce/content/pubs/indirreports/2011/RE,0311/rd03_11.pdf (Accessed: 8 March 2017).

Hillman, N. (2017) 'HE Bill: Amendments Do Not Mean Government Is Out of the Woods Just Yet.' Times Higher Education. Available at:

https://www.timeshighereducation.com/opinion/he-bill-amendments-do-not-meangovernment-out-woods-just-yet (Accessed: 1 March 2017).

Mezirow, J. (1997) Transformative Learning: Theory to Practice. Available at: http://www.hrdmax.com/images/column_1325932983/Mezirow\%20Transformative\%20Learni ng.pdf (Accessed: 7 March 2017).

Peter Davies, K. S. (2012) 'Variation in the length of an undergraduate degree: participation and outcomes.' Studies in Higher Education, 37(4), 431-447.

Scott, P. (2017) 'Ideological shakeup will create a squeezed middle of universities.' The Guardian. Available at: https://www.theguardian.com/education/2017/mar/07/ideologicalsqueezed-middle-universities-higher-education-bill (Accessed: 8 March 2017).

Stockwell, R. (2012) 'Two-year accelerated degrees: blue sky or in the red?' Blue Skies. Available at: http://pearsonblueskies.com/2012/two-year-accelerated-degrees-blue-sky-or-inthe-red/ (Accessed: 9 March 2017).

Washington State Council of Presidents (2016) Accelerated Degree Programs Work Group Report. Available at:

http://www.councilofpresidents.org/docs/reports/2016_12_COP_Report_Accelerated_Degre e.pdf (Accessed: 9 March 2017).

Yorke, H. (2017) 'Students to be offered university degrees over two years.' The Telegraph. Available at: http://www.telegraph.co.uk/education/2017/02/24/students-offered-universitydegrees-two-years/ (Accessed: 2 February 2017). 